\title{
An Empirical Study of Shanghai-Hong Kong Stock Connect Program and Financing Constraints under the Regulatory Effects
}

\author{
Xiaoxuan Yuan \\ International School, Jiangxi University of Finance and Economics, Nanchang, China
}

\begin{abstract}
Shanghai-Hong Kong Stock Connect Program began on July 17th, 2014, aiming to strengthen the cooperation in capital markets and promote the opening of domestic companies to the outside world. Based on DID and PSM-DID method, the article analyzes data sample from 2010 to 2017, exploring the effects of the program on financing constraints. It shows that ShanghaiHongkong Stock Connect Program alleviates financing constraints of underlying companies: If the institutional ownership is regarded as moderating variable, the financing constraints changes significantly; With the help of this program, enterprises with high investors attention and low tax rate are more likely to get rid of the dilemma of financing. According to the results, the government should keep promoting the development of capital markets and enterprises should learn from the outside world and constantly improve their management skills.
\end{abstract}

Keywords: Shanghai-Hong Kong Stock Connect Program; Financing Constrains; DID; PSM-DID.

\section{Introduction}

President Xi delivered important speeches in the Central Economic Working Conference, held in Beijing from December $8^{\text {th }}$ to $10^{\text {th }}$ in 2021 . According to President Xi, Socialist Market Economy is a remarkable invention and inevitably contains various forms of capital, which are expected to contribute to economic development of China in the future. However, due to the fact that external financing is costly, enterprises often face the problems of financing constraints, impeding capitals to function as well as expected. Therefore, solving the financing problem has become the key to promote the development of capital market.

In November 2014, the implementation of the Shanghai-Hong Kong Stock Connect Program established an unprecedented cooperation mechanism, broadened the financing channels of Shanghai and Hong Kong, and encouraged international investors to enter mainland stock market, which had a great impact on macroscopic financial market. Li Qiao (2021) found that, the Program made contributions to opening mainland capital market further by establishing offshore RMB backflow channels, reducing the difference of exchange rate and strengthening the linkage between two sides of cross-Straits; Zhang Zuominyang (2020) proved that, the program could enhance the risk spillover effect in Shanghai and Hong Kong as well as promote the development of individual enterprises; Ma Yaming et al. (2021) found that the implementation ofthe program can urge enterprises to improve the quality of accounting information disclosed, thus improving the corporate governance. Xin Yingying et al.(2021) found that the investment efficiency of objected enterprises was much higher than those without being objected and therefore concluded that the investment efficiency can be highly improved by the implementation of the program.

Other researchers also found, the effects of this program on financial market can be partly explained by its effects on financing constraints. Shi Qian \& Yao Qiuge (2018) took the KZ index as a measure of financing constraints and analyzed the impact of the launch of the program on variables such as analyst tracking and audit quality. They believed that the mechanism could reduce information asymmetry, alleviate agency problems, improve enterprise management and therefore reduce the risk of financing constraints; Yang Shenggang et al.(2020) found that the program reduced the financing constraints a lot especially on private enterprises, non-multinational enterprises and samples with high local judicial efficiency and marketization level; Zhou Fan(2016) proved that Shanghai-Hong Kong Stock Connect Program could encourage those enterprises to volunteer to disclose information, which would also reduce financing constraints. 
The marginal contribution of this article is as follow: First, taking the establishment of ShanghaiHong Kong Stock Connect as a starting point, it explores the effects of capital market opening on the financing constraints, which enriches the research on the influence factors of financing and guarantee the implementation of the opening-up policy theoretically. Second, it investigates whether institutional ownership has a moderating effect on the mechanism of the program affecting financing constraints, which provides a new perspective on researches for mechanism of financing constraints. During the process, SA indicator is used as measurement of the degree of financing constraints, for the purpose of relieving endogeneity problem.

\section{Theoretical Framework and Hypothesis}

The effects of Shanghai-Hong Kong Stock Connect Program on financing constraints can be divided into two categories:

On one hand, the program is able to attract more investors abroad, refine investor structure, broaden financing channels, and thereby ameliorate financing problems. Due to the fact that foreign investors usually ask highly for information quality and have a preference on international standards, domestic enterprises having to disclose high-quality information would attract more investors and capitals. Meanwhile, the policy could relieve information asymmetry, reducing moral hazard and adverse selection, for that investors would tend to invest more with those transparent and valuable information. The program also welcomes more advanced investment system and philosophy from abroad, because domestic enterprises can take its essence and apply those concepts to themselves, for example, giving some useful solutions to the financing dilemma.

On the other hand, the program might worsen financing for the following reasons: First, when excessive capitals enter the market, business out of abnormal optimism would require much more money, causing related corporations to be stuck in financing constraints, which can be recognized as vicious cycle. Another reason is that it's expensive for investors to get valuable and credible information and thus, it is hard to trust those companies to operate well. Therefore, corporations cannot have sustainable and long-term economic support. Based on the above theories, $\mathrm{H}_{1 \mathrm{a}}$ and $\mathrm{H}_{1 \mathrm{~b}}$ are proposed:

$\mathrm{H}_{1 \mathrm{a}}$ : The degree of financing constraints increases after Shanghai-Hong Kong Stock Connect Program.

$\mathrm{H}_{1 \mathrm{~b}}$ : The degree of financing constraints decreases after Shanghai-Hong Kong Stock Connect Program.

Yu Junyu (2021) found, institutional ownership could reduce the risk of information asymmetry and therefore relieve financing constraints. Firstly, institutional investors are expert at searching for information and their participation means introducing professional information gathering team to the company, which could relieve information asymmetry. Secondly, institutional investors play the role of infomediary. Under this circumstance, outside investors would rely on the information institutional investors give to them, which is usually objective and useful. Hence, the evaluated project or company would be less risky and the risk premium would decline as well, which would further reduce the cost of external finance. Thirdly, a relatively large percentage of institutional ownership implies high transparency of the company, which would leave a good impression on outside investors, making it easier to raise money. Finally, institutional investors can play a good role as corporate supervisors. If institutional investors can become board members, they can monitor corporate management, thus alleviating the principal-agent problem. Based on the above theories, $\mathrm{H}_{2}$ is proposed:

$\mathrm{H}_{2}$ : Institutional investors play the moderating role in the relationship between Shanghai-Hong Kong Stock Connect Program and financing constraints. 


\section{Model, Data and Variable Description}

\subsection{Model Specification}

Based on a quasi-natural experiment of Shanghai-Hong Kong Stock Connect Program, this article uses DID model to isolate the real impact of the policy, as follows:

$$
\mathrm{SA}_{\mathrm{i}, \mathrm{t}}=\alpha+\beta_{1} \text { Treat }^{*} \operatorname{Post}_{\mathrm{i}, \mathrm{t}}+\beta_{2} \mathrm{X}_{\mathrm{i}, \mathrm{t}}+\mathrm{Ind}_{\mathrm{i}}+\mathrm{Year}_{\mathrm{t}}+\varepsilon_{\mathrm{i}, \mathrm{t}}
$$

where i represents enterprise, t represents year. The explained variable SA is financing constraints; the core explanatory variable Treat*Post represents net effect of Shanghai-Hong Kong Stock Connect Program; X stands for a series of control variables; Ind denotes industry fixed effect; Year represents annual fixed effect; $\varepsilon$ is a random disturbance term. $\beta_{1}$ is the coefficient we focus on: being positive indicating that the program relieves financing constraints; otherwise, the program worsens financing constraints.

\subsection{Sample Selection and Data Sources}

Take A-share listed companies in Shanghai and Shenzhen from 2010 to 2017 as the initial samples from CSMAR, and do the following treatments: (1) Eliminate financial companies; (2) Eliminate ST, *ST and PT companies; (3) Eliminate newly added or removed stocks of the Shanghai-Hong Kong Stock Connect Program after November 2014; (4) Eliminate the samples with missing financial data; (5) Winsorize continuous variables at $1 \%$ level on both sides to eliminate the impact of extreme values. Finally, 8518 samples are obtained.

\subsection{Variables Selection}

\subsubsection{Explained Variables}

Financing constraints. There has not been a unified measurement of enterprise financing constraints in the academic circle so far, while KZ index( Kaplan \& Zingales, 1997), SA index (Hadlock \& Pierce, 2010) and WW index (Whited \& Wu, 2006) are widely used. In this article, SA index is utilized because of its exogeneity and timelessnes. This index has also been used by Shi Xiaokun (2017), Wang Jin (2015) and $\mathrm{Wu} \mathrm{Na}$ (2013). The computation formular of SA index is as follows:

$$
\mathrm{SA}=-0.737 \times \text { Size }+0.043 \times \operatorname{Size}^{2}-0.040 \times \text { Age }
$$

where Size represents the natural logarithm of year-end assets (in million yuan), and Age represents company age. The computed SAs are all negative, which are consistent to the computation result of Wang Bin (2021), Li Lin (2021) and Wu Wenjie (2021). The greater the absolute value of SA index, the severer the problem of financing constraint.

\subsubsection{Explanatory Variables}

The core explanatory variable is Shanghai-Hong Kong Stock Connect Program ( Treat*Post ), a dummy variable. Treat is a dummy variable to identify whether a listed company is an objected company of the program or not. If it is, Treat $=1$; otherwise, Treat $=0$. Post is a dummy variable indicating the launch time of the program. The program began on November $17^{\text {th }}, 2014$. Thus, if the time is from 2015 to 2017, Post $=1$; otherwise, Post $=0$.

\subsubsection{Moderating Variables}

The term "institutional investor" refers to a legal entity that uses its own funds or funds raised from the dispersed public to invest in securities exclusively. Because they play an important role in financing activities, proportion of institutional ownership (Percent) can be used as a moderating 
variable to influence the financing constraints of enterprises under the background Shanghai-Hong Kong Stock Connect Program.

\subsubsection{Control Variables}

Referring to the research of Shi Qian \& Yao Qiuge (2018), a series of control variables are introduced, including Return on assets, Debt-to-assets ratio, Growth, Company size, Enterprise age, Employee compensation, Proportion of the largest shareholder, Board size, Proportion of independent directors, and Integration of two positions. In addition, year and industry fixed effects are controlled, as shown in Table 1.

Table 1. Variable Definition Table

\begin{tabular}{|c|c|c|c|}
\hline Variable type & Variable name & $\begin{array}{l}\text { Variable } \\
\text { code }\end{array}$ & Variable definition \\
\hline $\begin{array}{c}\text { Explained } \\
\text { variables }\end{array}$ & Financing constraints & SA & See (2) above. \\
\hline $\begin{array}{c}\text { Moderating } \\
\text { variables }\end{array}$ & Institutional ownership & Percent & $\begin{array}{c}\text { Proportion of shares held by institutional investors } \\
\text { to total shares }\end{array}$ \\
\hline \multirow{2}{*}{$\begin{array}{l}\text { Explanatory } \\
\text { variables }\end{array}$} & Objected enterprises & Treat & $\begin{array}{c}\text { Dummy variables, Treat }=1 \text { if it's objected. } \\
\text { Otherwise, Treat }=0 \text {. }\end{array}$ \\
\hline & Establishment time point & Post & $\begin{array}{c}\text { Dummy variables, Post }=1 \text { if it's after } 2015 . \\
\text { Otherwise, Post }=0 .\end{array}$ \\
\hline \multirow{10}{*}{ Control variables } & Return on assets & Roa & Net income / Total assets \\
\hline & Debt-to-assets ratio & Lev & Total debts / Total assets \\
\hline & Growth & Growth & $\begin{array}{l}\text { (Current operating income - Previous operating } \\
\text { income) / Previous operating income }\end{array}$ \\
\hline & Company size & Size & Ln total assets at the end of the period \\
\hline & Enterprise age & Age & $\begin{array}{l}\text { Ln age since the establishment of the } \\
\text { Enterprise }\end{array}$ \\
\hline & Employee compensation & Wage & Ln employee wage payables at the end of the period \\
\hline & $\begin{array}{l}\text { Proportion of the largest } \\
\text { shareholder }\end{array}$ & Top1 & $\begin{array}{l}\text { Proportion of the shares held by the largest } \\
\text { shareholder to the total shares at the end of the } \\
\text { period }\end{array}$ \\
\hline & Board size & Board & Ln the number of directors at the end of the period \\
\hline & $\begin{array}{c}\text { Proportion of } \\
\text { independent directors }\end{array}$ & Indep & $\begin{array}{c}\text { Proportion of independent directors to total } \\
\text { directors }\end{array}$ \\
\hline & $\begin{array}{l}\text { Integration of two } \\
\text { positions }\end{array}$ & Dual & $\begin{array}{l}\text { Dummy variables, Dual }=1 \text { if the chairman and the } \\
\text { general manager are the same. Otherwise, Dual }=0 \text {. }\end{array}$ \\
\hline \multirow{2}{*}{ Dummy variables } & Year fixed effect & Year & Annual dummy variable \\
\hline & Industry fixed effect & Ind & Industry dummy variable \\
\hline
\end{tabular}

\subsection{Descriptive Statistical Analysis}

Table 2. Descriptive Statistics of Main Variables

\begin{tabular}{|c|c|c|c|c|c|c|c|c|c|}
\hline \multirow{2}{*}{ Variable } & \multicolumn{3}{|c|}{ Full sample } & \multicolumn{3}{c|}{ Control } & \multicolumn{3}{c|}{ Treated } \\
\cline { 2 - 11 } & Obs & Mean & Std.Dev. & Obs & Mean & Std.Dev. & Obs & Mean & Std.Dev. \\
\hline SA & 8,518 & -3.201 & 0.100 & 7,986 & -3.201 & 0.099 & 532 & -3.202 & 0.114 \\
\hline Roa & 8,518 & 0.047 & 0.053 & 7,986 & 0.047 & 0.053 & 532 & 0.054 & 0.057 \\
\hline Lev & 8,518 & 0.410 & 0.215 & 7,986 & 0.407 & 0.215 & 532 & 0.447 & 0.205 \\
\hline Growth & 8,518 & 0.285 & 0.665 & 7,986 & 0.279 & 0.641 & 532 & 0.371 & 0.944 \\
\hline Size & 8,518 & 8.224 & 1.170 & 7,986 & 8.200 & 1.168 & 532 & 8.590 & 1.133 \\
\hline Age & 8,518 & 2.668 & 0.432 & 7,986 & 2.680 & 0.409 & 532 & 2.487 & 0.667 \\
\hline Wage & 8,518 & 16.890 & 1.521 & 7,986 & 16.860 & 1.525 & 532 & 17.310 & 1.391 \\
\hline Top1 & 8,518 & 0.350 & 0.150 & 7,986 & 0.346 & 0.149 & 532 & 0.407 & 0.159 \\
\hline Board & 8,518 & 2.130 & 0.190 & 7,986 & 2.130 & 0.190 & 532 & 2.120 & 0.191 \\
\hline Indep & 8,518 & 0.374 & 0.054 & 7,986 & 0.374 & 0.054 & 532 & 0.373 & 0.050 \\
\hline Dual & 8,518 & 0.288 & 0.453 & 7,986 & 0.292 & 0.455 & 532 & 0.227 & 0.420 \\
\hline
\end{tabular}


Table 2 lists descriptive statistical results for the full sample, control group, and treatment group.

\subsection{Correlation Analysis}

Table 3 lists the correlation coefficients of the main variables. It can be seen that the absolute correlation coefficients of regression explanatory variables are all less than 0.6 , so there is no serious multicollinearity between explanatory variables and control variables.

Table 3. Correlation Coefficient of Main Variables

\begin{tabular}{|c|c|c|c|c|c|c|c|c|c|c|c|c|}
\hline \\
\hline & SA & Treat & Post & Roa & Leverage & Growth & Size & Age & Top1 & Board & Indep & Dual \\
\hline SA & 1 & & & & & & & & & & & \\
\hline Treat & -0.001 & 1 & & & & & & & & & & \\
\hline Post & $-0.097^{* * *}$ & $0.062^{* * *}$ & 1 & & & & & & & & & \\
\hline Roa & $-0.029^{* * *}$ & $0.044^{* * *}$ & $-0.020^{*}$ & 1 & & & & & & & & \\
\hline Lev & -0.016 & $0.155^{* * *}$ & -0.006 & $0.400^{* * *}$ & 1 & & & & & & & \\
\hline Growth & 0.002 & $0.038^{* * *}$ & $0.035^{* * *}$ & $0.145^{* * *}$ & $0.063^{* * *}$ & 1 & & & & & & \\
\hline Size & $-0.095^{* * *}$ & $0.019^{*}$ & $0.261^{* * *}$ & $0.091^{* * *}$ & $0.512^{* * *}$ & $0.044^{* * *}$ & 1 & & & & & \\
\hline Age & $-0.090^{* * * *}$ & $0.081^{* * *}$ & $0.207^{* * *}$ & $0.188^{* * *}$ & $0.394^{* * *}$ & 0.014 & $0.287^{* * *}$ & 1 & & & & \\
\hline Top1 & $-0.024^{* *}$ & $0.114^{* * *}$ & $0.093^{* * *}$ & $0.063^{* * *}$ & $0.090^{* * *}$ & 0.003 & $0.145^{* * *}$ & $0.018^{*}$ & 1 & & & \\
\hline Board & $-0.026^{* *}$ & -0.007 & $0.078^{* * *}$ & 0 & $0.114^{* * *}$ & $-0.037^{* * *}$ & $0.205^{* * *}$ & $0.146^{* * *}$ & $-0.020^{*}$ & 1 & & \\
\hline Indep & $0.054^{* * *}$ & -0.008 & $0.030^{* * *}$ & 0.004 & $-0.027^{* *}$ & 0.015 & -0.007 & $-0.022^{* *}$ & $0.031^{* * *}$ & $0.541^{* * *}$ & 1 & \\
\hline Dual & $0.085^{* * *}$ & $0.087^{* * *}$ & $0.023^{* *}$ & $0.062^{* * *}$ & $-0.124^{* * *}$ & 0.014 & $0.124^{* * *}$ & $0.215^{* * *}$ & $0.031^{* * *}$ & $0.153^{* * *}$ & $0.114^{* * *}$ & 1 \\
\hline
\end{tabular}

Note: $* * *, * *, *$ indicate the significance level of $1 \%, 5 \%$, and $10 \%$ respectively.

\section{Empirical Results and Analysis}

\subsection{Analysis of Multiple Regression Results}

\subsubsection{Results of Baseline Regression}

The baseline regression results are shown in Column (1) and Column (2) of Table 4. The study in Column (1) does not control industry and year fixed effect, while in Column (2) it does. It can be seen that the both coefficients of Post*Treat are significantly positive, indicating that the program significantly relieves financing constraint, which verifies the hypothesis $\mathrm{H}_{1 \mathrm{~b}}$.

\subsubsection{PSM-DID}

Since the objected companies were not randomly selected, the individual characteristics of the treatment group and the control group may differ greatly before the program, which leads to sample selection bias. To reduce the impact of individual inherent differences between these two groups on the results, this paper adopts the nearest neighbor matching method to conduct 1:1 matching, and then DID regression is conducted. To realize it, Logit model is needed:

$$
\begin{gathered}
\mathrm{Y}_{\mathrm{i}}=\alpha_{0}+\alpha_{1} \text { Roa }_{\mathrm{i}, \mathrm{t}}+\alpha_{2} \operatorname{Lev}_{\mathrm{i}, \mathrm{t}}+\alpha_{3} \text { Growth }_{\mathrm{i}, \mathrm{t}}+\alpha_{4} \text { Size }_{\mathrm{i}, \mathrm{t}}+\alpha_{5} \text { Age }_{\mathrm{i}, \mathrm{t}}+\alpha_{6} \text { Wage }_{\mathrm{i}, \mathrm{t}} \\
+\alpha_{7} \text { Top }_{\mathrm{i}, \mathrm{t}}+\alpha_{8} \text { Board }_{\mathrm{i}, \mathrm{t}}+\alpha_{9} \operatorname{Indep}_{\mathrm{i}, \mathrm{t}}+\alpha_{10} \text { Dual }_{\mathrm{i}, \mathrm{t}}+\varepsilon_{\mathrm{i}, \mathrm{t}}
\end{gathered}
$$

In the above model, the objected company $(\mathrm{Y})$ is used as the explained variable. If it is objected, $Y=1$. Otherwise, $Y=0$. The explanatory variables are return on assets (Roa), debt-assets ratio (Lev), growth (Growth), company size (Size), enterprise age (Age), employee compensation (Wage), proportion of the largest shareholder (Top1), Board Size (Board), proportion of independent directors (Indep), and Integration of two positions (Dual) and other enterprise characteristic variables.

Table 5 reports the sample characteristics before and after matching. It can be seen that after matching, the biases of Roa, Lev, Growth, Size and other variables are less than $6 \%$ and the $t$ value is not significant, indicating that the matching result is desired. Figure1 plots the Kernel Density Map, which shows that the propensity scores of the treatment group and the control group overlap in a large range. It can be seen that the PSM matching effect is desired and the therefore parallelism hypothesis is met from Table 5 and Figure 1. 
Table 4. The Regression Results

\begin{tabular}{|c|c|c|c|}
\hline \multirow{2}{*}{ Variable } & \multicolumn{2}{|c|}{ DID } & \multirow{2}{*}{$\begin{array}{c}\text { DID-PSM } \\
(3)\end{array}$} \\
\hline & (1) & (2) & \\
\hline \multirow[t]{2}{*}{ Treat ${ }^{*}$ Post } & $0.0105^{*}$ & $0.0130^{* *}$ & $0.0130^{* *}$ \\
\hline & $(-0.0056)$ & $(-0.0056)$ & $(0.0056)$ \\
\hline \multirow[t]{2}{*}{ Treat } & -0.0011 & -0.0028 & -0.0027 \\
\hline & $(-0.0041)$ & $(-0.0041)$ & $(0.0041)$ \\
\hline \multirow[t]{2}{*}{ Post } & $-0.0181^{* * *}$ & $-0.0335^{* * *}$ & $-0.0278 * * *$ \\
\hline & $(-0.0020)$ & $(-0.0041)$ & $(0.0041)$ \\
\hline \multirow[t]{2}{*}{ Roa } & $-0.0687^{* * *}$ & $-0.0647^{* * *}$ & $-0.0616^{* * *}$ \\
\hline & $(-0.0193)$ & $(-0.0196)$ & $(0.0193)$ \\
\hline \multirow[t]{2}{*}{ Lev } & -0.0072 & $-0.0115^{* *}$ & $-0.0110^{* *}$ \\
\hline & $(-0.0050)$ & $(-0.0054)$ & $(0.0054)$ \\
\hline \multirow[t]{2}{*}{ Growth } & 0.0015 & 0.0012 & $2.68 \mathrm{e}-06^{* *}$ \\
\hline & $(-0.0014)$ & $(-0.0014)$ & $(1.35 \mathrm{e}-06)$ \\
\hline \multirow[t]{2}{*}{ Wage } & -0.0009 & -0.0010 & -0.0010 \\
\hline & $(-0.0007)$ & $(-0.0007)$ & $(0.0007)$ \\
\hline \multirow[t]{2}{*}{ Top1 } & $-0.0162^{* * *}$ & $-0.0236^{* * *}$ & $-0.0236^{* * *}$ \\
\hline & $(-0.0061)$ & $(-0.0063)$ & $(0.0063)$ \\
\hline \multirow[t]{2}{*}{ Board } & 0.0054 & 0 & $-1.87 \mathrm{E}-05$ \\
\hline & $(-0.0058)$ & $(-0.0059)$ & $(-0.0059)$ \\
\hline \multirow[t]{2}{*}{ Indep } & $0.0842^{* * *}$ & $0.0640^{* * *}$ & $0.0638 * * *$ \\
\hline & $(-0.0199)$ & $(-0.0201)$ & $(-0.0201)$ \\
\hline \multirow[t]{2}{*}{ Dual } & $0.0151^{* * *}$ & $0.0152^{* * *}$ & $0.0153 * * *$ \\
\hline & $(-0.0020)$ & $(-0.0020)$ & $(-0.0020)$ \\
\hline \multirow[t]{2}{*}{ Constant } & $-3.2160^{* * *}$ & $-3.1980^{* * *}$ & $-3.1780^{* * *}$ \\
\hline & -0.0188 & -0.0237 & $(0.0196)$ \\
\hline Year fixed effect & No & Yes & Yes \\
\hline Industry fixed effect & No & Yes & Yes \\
\hline Observations & 8518 & 8518 & 8518 \\
\hline R-squared & 0.023 & 0.072 & 0.028 \\
\hline
\end{tabular}

Note: Standard error in parentheses; $* * *, * *, *$ indicate the significance level of $1 \%, 5 \%$, and $10 \%$ respectively; Variables Size and Age are required to calculate SA index, which are no longer used in regression.

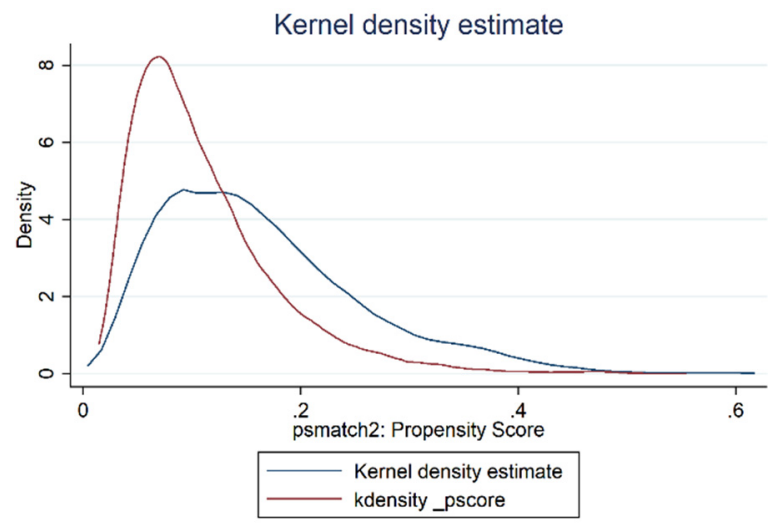

Unmatched

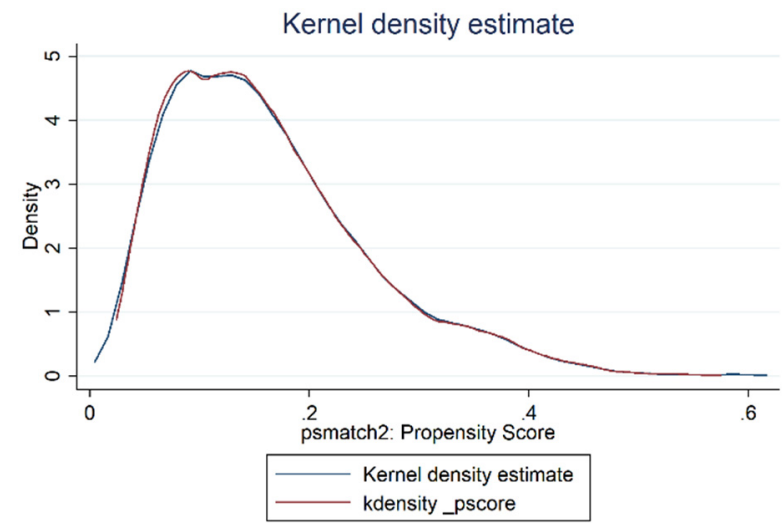

Matched

Figure 1. Comparison of propensity scores between treatment group and control group before and after PSM matching 
Table 5. Comparison of Sample Features before and after Matching

\begin{tabular}{|c|c|c|c|c|c|c|}
\hline \multirow{2}{*}{ Variable } & \multirow{2}{*}{ Sample } & \multicolumn{2}{|c|}{ Mean } & \multirow{2}{*}{$\%$ Bias } & \multirow{2}{*}{$\%$ Reduct bias } & \multirow{2}{*}{$\mathrm{t}$} \\
\hline & & Treated & Control & & & \\
\hline \multirow{2}{*}{ Roa } & Unmatched & 0.04086 & 0.04802 & -12.8 & \multirow{2}{*}{80.0} & -4.03 \\
\hline & Matched & 0.04086 & 0.03943 & 2.6 & & 0.56 \\
\hline \multirow{2}{*}{ Lev } & Unmatched & 0.50045 & 0.39747 & 47.8 & \multirow{2}{*}{99.0} & 14.45 \\
\hline & Matched & 0.50013 & 0.49908 & 0.5 & & 0.11 \\
\hline \multirow{2}{*}{ Growth } & Unmatched & 8.09850 & 10.36200 & -0.5 & \multirow{2}{*}{-11.3} & -0.10 \\
\hline & Matched & 8.10670 & 5.58780 & 0.5 & & 0.44 \\
\hline \multirow{2}{*}{ Size } & Unmatched & 8.28510 & 8.21980 & 5.7 & \multirow{2}{*}{86.0} & 1.72 \\
\hline & Matched & 8.28530 & 8.29440 & -0.8 & & -0.18 \\
\hline \multirow{2}{*}{ Age } & Unmatched & 2.76440 & 2.65550 & 21.5 & \multirow{2}{*}{98.3} & 7.52 \\
\hline & Matched & 2.76390 & 2.76210 & 0.4 & & 0.08 \\
\hline \multirow{2}{*}{ Wage } & Unmatched & 16.81000 & 16.89800 & -5.6 & \multirow{2}{*}{18.9} & -1.71 \\
\hline & Matched & 16.81400 & 16.88500 & -4.5 & & -1.00 \\
\hline \multirow{2}{*}{ Top1 } & Unmatched & 0.39635 & 0.34344 & 34.6 & \multirow{2}{*}{83.1} & 10.55 \\
\hline & Matched & 0.39601 & 0.40493 & -5.8 & & -1.28 \\
\hline \multirow{2}{*}{ Board } & Unmatched & 2.12580 & 2.13010 & -2.2 & \multirow{2}{*}{-70.4} & -0.67 \\
\hline & Matched & 2.12640 & 2.11910 & 3.7 & & 0.83 \\
\hline \multirow{2}{*}{ Indep } & Unmatched & 0.37227 & 0.37367 & -2.6 & \multirow{2}{*}{15.1} & -0.77 \\
\hline & Matched & 0.37224 & 0.37106 & 2.2 & & 0.52 \\
\hline \multirow{2}{*}{ Dual } & Unmatched & 0.18010 & 0.30281 & -29.0 & \multirow{2}{*}{83.8} & -8.10 \\
\hline & Matched & 0.18028 & 0.20020 & -4.7 & & -1.14 \\
\hline
\end{tabular}

As shown in Column (3) of Table 4, regression is performed after PSM matching, year fixed effects and industry fixed effect being controlled. It is reported that the coefficient of the interaction is 0.013 and the significance level is $5 \%$, which indicates that the program significantly relieves financing constraints of objected enterprises.

\subsection{Robustness Test}

\subsubsection{Parallel Trend Test}

Parallel trend means that the treatment group and the control group must have the same trend before the policy. Otherwise, the differences we observe after the policy may not be completely caused by the establishment of the program but the two groups themselves. Hence, the premise of using DID method is to experience the parallel trend test.

In this article, the event study approach is used, and the coefficients of interaction terms reflect the differences between the treatment group and the control group in a particular year. To avoid the problem of perfect collinearity, the first year before the program is thrown. Reference to Bertrand \& Mullainathan (2003), formula (4) is as follows:

$$
\begin{aligned}
\text { SA }_{i, t}= & \alpha+\beta_{1} \text { Before }_{i, t}+\beta_{2} \text { Before }_{i, t}+\beta_{3} \text { Before }_{i, t}+\beta_{4} \text { Before }_{i, t} \\
& +\beta_{5} \text { Current }_{i, t}+\beta_{6} \text { After }_{i, t}+\gamma X_{i, t}+\operatorname{Ind}_{i}+\text { Year }_{t}+\varepsilon_{i, t}
\end{aligned}
$$

where Before4, Before3, Before2, Before1, Current, and After1 are all dummy variables, representing whether the enterprise is in the first four years, three years, two years, one-year, current year and one year after the implementation of the Shanghai-Hong Kong Stock Connect Program respectively. Table 6 shows the parallel trend test results. The coefficients of Before4, Before 3 and Before 2 are not significant, indicating the differences between the treatment group and the control group have no significant impact on the experiment, and the results of the test support the hypothesis in this paper. 
Table 6. Parallel Trend Test

\begin{tabular}{|c|c|}
\hline Variable & SA \\
\hline Before4 & 0.0063 \\
\hline & $(-0.0097)$ \\
\hline Before3 & 0.0115 \\
\hline Before2 & $(-0.0091)$ \\
\hline & -0.0120 \\
\hline Current & $(-0.0089)$ \\
\hline & -0.0063 \\
\hline After1 & $(-0.0087)$ \\
\hline & 0.0043 \\
\hline Constant & $(-0.0076)$ \\
\hline & 0.0013 \\
\hline Year fixed effect & $(-0.0069)$ \\
\hline Industry fixed effect & Yes \\
\hline Observations & Yes \\
\hline R-squared & 8,518 \\
\hline
\end{tabular}

Note: Standard error in parentheses; $* * *, * *, *$ indicate the significance level of $1 \%, 5 \%$, and $10 \%$ respectively.

\subsubsection{Variable Substitution}

To test the robustness of the empirical results, the explained variable is substituted to KZ index to measure financing constraints, which was acquired by Lamont et al. (2001). They selected five financial variables, including net operating cash flow, dividends payable, cash, Tobin Q and debtassets ratio to construct $\mathrm{KZ}$ index model by regressing an ordered Logistic model. Based on the result, 8189 samples of A-shares listed in Shanghai and Shenzhen are adopted to gain the following formula:

$$
\mathrm{KZ}=-9.156 \times \mathrm{CF}-6.883 \times \mathrm{DIV}-3.781 \times \mathrm{Cash}+4.912 \times \mathrm{LEV}+0.456 \times \text { TobinQ }
$$

where CF represents net operating cash flow / total assets of previous period; DIV represents cash dividend / total assets of previous period; Cash represents cash / total assets of the previous period; LEV represents debt-assets ratio; TobinQ represents Tobin $Q$ value. The larger the KZ index is, the heavier the financing constraints are. Column (1) of Table 7 shows the results of this regression. The coefficient of interaction is negative, so the interaction term is negatively correlated with $\mathrm{KZ}$ index, which is basically consistent with the baseline regression.

\subsubsection{Endogenous Problems}

In order to further test the robustness and endogeneity of the results, the explanatory variables will be delayed by one stage before regression. Column (2) of Table 7 shows the regression results. The coefficient of Treat*Post was -0.0083 and passed the test at the confidence level of $10 \%$. Compared with Column (2) of Table 4, the result was basically unchanged, which supported the easing effect of Shanghai-Hong Kong Stock Connect Program on corporate financing constraints.

\subsubsection{Placebo Test}

In order to eliminate the possibility of random results, the article randomly selects 532 enterprises from 1396 original samples and sets them as the fake treatment group, and the remaining 864 enterprises as the fake control group to construct a fake dummy variable for placebo test according to the method of Cai at al. (2016). Figure 2 graphs the kernel density of the estimated coefficient and the corresponding T-value distribution for 500 times. It can be seen that the estimated coefficient and $t$ value are all concentrated near zero for 500 times, implying that the relief of financing constraints is caused by the Shanghai-Hong Kong Stock Connect Program and the research result is robust. 
Table 7. Robustness Test

\begin{tabular}{|c|c|c|}
\hline \multirow{2}{*}{ Variable } & $\mathrm{KZ}$ & L.SA \\
\hline & (1) & $(2)$ \\
\hline \multirow[t]{2}{*}{ Treat ${ }^{*}$ Post } & $-0.9100^{*}$ & $-0.0083^{*}$ \\
\hline & $(0.4830)$ & $(-0.0048)$ \\
\hline \multirow[t]{2}{*}{ Treat } & $0.6240^{*}$ & $0.0072^{* *}$ \\
\hline & $(0.3550)$ & $(-0.0036)$ \\
\hline \multirow[t]{2}{*}{ Post } & $0.6290^{*}$ & $0.0144^{* * *}$ \\
\hline & $(0.3650)$ & $(-0.0029)$ \\
\hline \multirow[t]{2}{*}{ Roa } & -1.0740 & $0.0808^{* * *}$ \\
\hline & $(1.7270)$ & $(-0.0168)$ \\
\hline \multirow[t]{2}{*}{ Lev } & $8.4830^{* * *}$ & $0.0463^{* * *}$ \\
\hline & $(0.5170)$ & $(-0.0048)$ \\
\hline \multirow[t]{2}{*}{ Growth } & $-3.1550^{* * *}$ & $-0.0218^{* * *}$ \\
\hline & $(0.1210)$ & $(-0.0025)$ \\
\hline \multirow{2}{*}{ Size } & $-0.409^{* * *}$ & \\
\hline & $(0.1120)$ & \\
\hline \multirow[t]{2}{*}{ Age } & -0.1460 & \\
\hline & $(0.2260)$ & \\
\hline \multirow[t]{2}{*}{ Wage } & $-0.2160^{* * *}$ & $0.0022^{* * *}$ \\
\hline & $(0.0697)$ & $(-0.0006)$ \\
\hline \multirow[t]{2}{*}{ Top1 } & $-1.9120^{* * *}$ & $0.0117^{* *}$ \\
\hline & $(0.5460)$ & $(-0.0057)$ \\
\hline \multirow[t]{2}{*}{ Board } & -0.3670 & $0.0199^{* * *}$ \\
\hline & $(0.5130)$ & $(-0.0062)$ \\
\hline \multirow[t]{2}{*}{ Indep } & 0.2240 & -0.0080 \\
\hline & $(1.7290)$ & $(-0.0195)$ \\
\hline \multirow[t]{2}{*}{ Dual } & 0.1020 & $-0.0106^{* * *}$ \\
\hline & $(0.1760)$ & $(-0.0017)$ \\
\hline \multirow[t]{2}{*}{ Constant } & $13.0600^{* * *}$ & $3.1060^{* * *}$ \\
\hline & $(-2.4910)$ & $(-0.0227)$ \\
\hline control year & Yes & Yes \\
\hline control industry & Yes & Yes \\
\hline Observations & 8,189 & 7,059 \\
\hline R-squared & 0.1228 & 0.118 \\
\hline
\end{tabular}

Note: Standard error in parentheses; $* * *, * *, *$ indicate the significance level of $1 \%, 5 \%$, and $10 \%$ respectively; Variables Size and Age are required to calculate SA index, which are no longer used in regression.

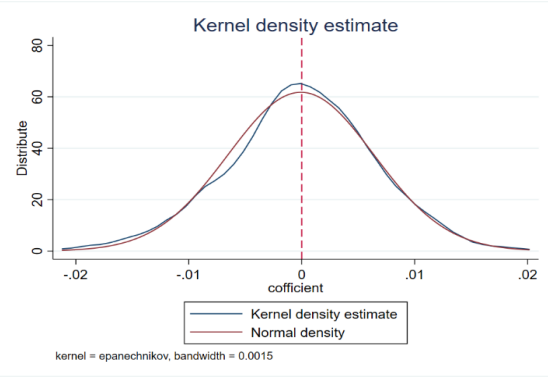

Coefficient Distribution

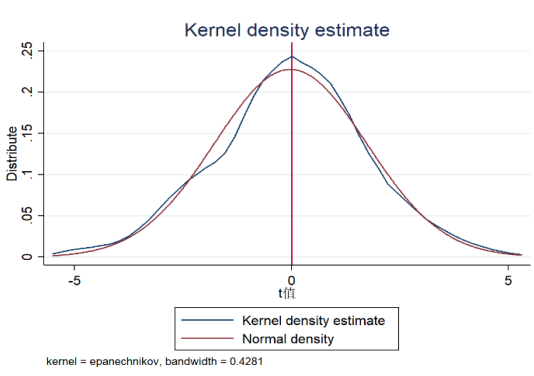

T-Value Distribution

Figure 2. Estimated Coefficients after Randomization 


\section{Regulatory Effects Test}

As mentioned in Part 2, institutional investors can help to relieve the financing constraints by reducing the risk of information asymmetry. Therefore, institutional ownership is selected as the potential moderating variable in this article, and its model is as follows:

$$
\begin{aligned}
& \mathrm{SA}_{\mathrm{i}, \mathrm{t}}=\alpha+\beta_{1} \text { Treat }^{*} \text { Post }_{\mathrm{i}, \mathrm{t}} \times \text { Percent }_{\mathrm{i}, \mathrm{t}}+\beta_{2} \text { Treat }^{*} \text { Post }_{\mathrm{i}, \mathrm{t}}+\beta_{3} \text { Percent }_{\mathrm{i}, \mathrm{t}} \\
&+\gamma \mathrm{X}_{\mathrm{i}, \mathrm{t}}+\text { Year }_{\mathrm{t}}+\operatorname{Ind}_{\mathrm{i}}+\varepsilon_{\mathrm{i}, \mathrm{t}}
\end{aligned}
$$

In the above formular, Percent represents institutional ownership. Table 8 shows the results of the moderating effect, where column (1) controls the industry fixed effect and year fixed effect, and column (2) does not. The result shows that the coefficient of the interaction term Treat*Post*Percent is positive and significant at $1 \%$, which proves that institutional ownership has a positive moderating effect on the relationship between Shanghai-Hong Kong Stock Connect Program and financing constraints. Therefore, $\mathrm{H}_{2}$ is verified, that is, the higher the shareholding of institutional investors, the less likely enterprises are constrained by financing.

Table 8. Regulatory Effect Test

\begin{tabular}{|c|c|c|}
\hline \multirow{2}{*}{ Variable } & \multicolumn{2}{|c|}{ SA } \\
\cline { 2 - 3 } & $(1)$ & $(2)$ \\
\hline Treat ${ }^{*}$ Post ${ }^{*}$ Percent & $0.080^{* * *}$ & $0.001^{* * *}$ \\
\hline & $(-0.019)$ & $(-0.001)$ \\
\hline Treat ${ }^{*}$ Post & -0.007 & 0 \\
\hline & $(-0.005)$ & $(-0.005)$ \\
\hline Percent & $-0.007^{*}$ & $(0)$ \\
\hline & $(-0.004)$ & $-3.203^{* * *}$ \\
\hline Constant & $-3.200^{* * *}$ & $(-0.016)$ \\
\hline & $(-0.002)$ & No \\
\hline Year fixed effect & Yes & No \\
\hline Industry fixed effect & Yes & 6,996 \\
\hline Observations & 6,996 & 0.067 \\
\hline R-squared & 0.003 & $0,5 \%, a n d ~$ \\
\hline
\end{tabular}

Note: Standard error in parentheses; $* * *, * *, *$ indicate the significance level of $1 \%, 5 \%$, and $10 \%$ respectively.

\section{Heterogeneity Test}

\subsection{Analysis of Difference in Investor Attention}

Investors' attention can influence the enterprise financing constraints, which can be explained by the following points. Firstly, when investors increase their attention, they are willing to take the initiative to know about the company, such as the state of operation and the management structure. With extra information, the problem of information asymmetry can be alleviated resulting in cost saving as well as less financing constraints. Secondly, more investors' attention usually means a boost in investment sentiment. In that case, investors tend to be overconfident in the projects they value and are willing to invest more, thus easing the financing constraints of enterprises. Lastly, the non-public information obtained by investors may be transmitted among a few people. They are willing to pay a higher price than the market price to obtain extra returns, which can ultimately alleviate corporate financing constraints.

Based on the study of Tang Xiaodong, Lin Yongjian and Xiao Qi (2021), the annual turnover rate are used as the measure of investors' attention. The median annual turnover rate is $500.2513 \%$, 
regarded as a threshold. Enterprises with higher turnover rate indicate higher investors' attention, and the remaining enterprises are with lower investors' attention. Columns (1) and (2) of Table 9 report the regression results of sub-sample. It can be seen that enterprises with high investors' attention are significant at $1 \%$ level, while others are not, indicating that after the implementation of ShanghaiHong Kong Stock Connect Program, enterprises with high investors' attention are faced with less financing constraints.

\subsection{Analysis of Differences in Effective Tax Rate}

The effective tax rate would also affect financing constraints. With lower tax rate, the retained earnings of the enterprise will be higher. In that case, instead of borrowing capitals from outside, lowtaxed companies can largely finance with their retained earnings. Conversely, those corporates paying more taxes have to raise from the outside and it's more likely to get struggled with financing constraints. To verify the rationality above, Columns (3) and (4) of Table 9 list the regression results, which divided the samples into enterprises with high and low tax rate according to the median effective tax rate of full samples. It shows that the coefficient of interaction term is significantly positive in the regression of enterprises with low tax rate, while the other is not. It indicates that the establishment of the Shanghai-Hong Kong Stock Connect Program significantly solves the problem of external financing for low-tax enterprises.

Table 9. Heterogeneity Test

\begin{tabular}{|c|c|c|c|c|}
\hline \multirow{2}{*}{ Variable } & \multicolumn{4}{|c|}{ SA } \\
\cline { 2 - 5 } & $\begin{array}{c}\text { Enterprises with high } \\
\text { investors' attention }\end{array}$ & $\begin{array}{c}\text { Enterprises with low } \\
\text { investors' attention }\end{array}$ & $\begin{array}{c}\text { Enterprises with } \\
\text { high tax rate }\end{array}$ & $\begin{array}{c}\text { Enterprises with } \\
\text { low tax rate }\end{array}$ \\
\cline { 2 - 5 } & $(1)$ & $(2)$ & $(3)$ & $(4)$ \\
\hline Treat ${ }^{*}$ Post & $0.0194^{* * *}$ & -0.000158 & 0.009 & $0.028^{* * *}$ \\
\hline & -0.00696 & -0.0085 & -0.010 & -0.010 \\
\hline Treat & -0.00485 & 0.00723 & 0.004 & $-0.020^{* * *}$ \\
\hline Post & -0.0056 & -0.00567 & -0.007 & -0.007 \\
\hline & $-0.0146^{* * *}$ & $-0.0247^{* * *}$ & -0.007 & $-0.050^{* * *}$ \\
\hline Constant & -0.00489 & -0.00728 & -0.007 & -0.007 \\
\hline & $-3.024^{* * *}$ & $-3.395^{* * *}$ & $-3.232^{* * *}$ & $-3.185^{* * *}$ \\
\hline Control & -0.03 & -0.0352 & -0.043 & -0.015 \\
\hline $\begin{array}{c}\text { Year fixed } \\
\text { effect }\end{array}$ & Yes & Yes & Yes & Yes \\
\hline $\begin{array}{c}\text { Industry fixed } \\
\text { effect }\end{array}$ & Yes & Yes & Yes & Yes \\
\hline Observations & 5,823 & Yes & Yes & Yes \\
\hline AdjR-squared & 0.0657 & 2,695 & 4,088 & 4,088 \\
\hline
\end{tabular}

Note: Standard error in parentheses; $* * *, * *, *$ indicate the significance level of $1 \%, 5 \%$, and $10 \%$ respectively.

\section{Conclusion and Implication}

With data from A-share listed companies in Shanghai and Shenzhen from 2010 to 2017 and SA index as the measurement of financing constraints, this paper takes the Shanghai-Hong Kong Stock Connect Program as a quasi-natural experiment and investigates the impact of the implementation of Shanghai-Hong Kong Stock Connect Program on corporates' financing constraints, using DID model and PSM method. The result shows that the establishment of the program alleviates the corporate financing constraints. This remains true after robustness tests including parallel trend tests, variable substitutions, endogeneity problems, and placebo tests. Further research shows that institutional 
ownership has a positive moderating effect on the relationship between the program and financing constraints, which should be paid attention by companies. In addition, with regard to the heterogeneity test, it is found that under the background of Shanghai-Hong Kong Stock Connect Program, enterprises with higher investors' attention benefit more from the program. Also, the lower the effective tax rate is, the less likely it is to be constrained by corporate financing.

Considering the above analysis, several suggestions are made. First, government should carry out further policies to help the opening up of the domestic capital market so that inland enterprises would have more opportunities to learn advanced management experience from outside world and update their own cognitive competence; Second, the administration needs to reduce the burden on enterprises. For example, the tax payment should be properly reduced for companies to be more motivated to improve their operation with retained earnings. Third, enterprises should optimize their governance structure. For example, companies should widely introduce institutional investors into their management team, because they can supervise the businesses of enterprises and transmit positive signals to the outside world, which is conducive to, for instance, corporate image building and financing loans. Last but not least, companies should take the initiative to disclose relevant information and improve the transparency of the entities, which could reduce the risk of market information asymmetry, weaken the principal-agent risk, and most importantly, facilitate financing.

\section{References}

[1] Bertrand M., Mullainathan S. Enjoying the quiet life? Corporate governance and managerial preferences [J]. Journal of political Economy, 2003, 111(5): 1043-1075.

[2] Cai H., Zhao Q. Q., Peng S. Y. A review of the literature on measurement methods of corporate financing Constraints[J]. National Circulation Economy,2021(12):56-58.

[3] Cai X., Lu Y., Wu M., et al. Does environmental regulation drive away inbound foreign direct investment? Evidence from a quasi-natural experiment in China[J]. Journal of Development Economics, 2016, 123: 73-85.

[4] Gao Y. Q., Shu Y. K., Sunkai. Does replacing business tax with VALUE-ADDED tax Reduce Corporate tax burden: A quasi-natural experiment based on transportation Industry [J]. Journal of Hunan University of Science and Technology (Social Science Edition), 201,24(01):59-66.

[5] Hadlock C. J., Pierce J. R. New evidence on measuring financial constraints: Moving beyond the KZ index[J]. The Review of Financial Studies, 2010, 23(5): 1909-1940.

[6] Kaplan S. N., Zingales L. Do investment-cash flow sensitivities provide useful measures of financing constraints? [J]. The quarterly journal of economics, 1997, 112(1): 169-215.

[7] Lamont O., Polk C., Saaá-Requejo J. Financial constraints and stock returns[J]. The review of financial studies, 2001, 14(2): 529-554.

[8] Li Q. Analysis on the coactivity of RMB offshore exchange rate market -- based on the background of Shanghai-Hong Kong Stock Connect Program [J]. North China Finance,2021(02):18-27.

[9] Liu Y., Zang R. H. Capital market opening and firm innovation: Based on empirical data of ShanghaiHong Kong Stock Connect Program [J]. Journal of Beijing Technology and Business University (Social Science Edition), 201,36(03):79-90.

[10] Lu S. Y., Zhou F. The impact of capital market opening on firm investment and financing behavior: An empirical test based on Shanghai-Hong Kong Stock Connect Effect [J]. Northern Economics and Trade, 2021 (05):14-18.

[11] Shi Q., Yao Q. G. Shanghai-hong Kong Stock Connect Program and corporate financing constraints: An empirical study based on differential difference model [J]. Financial Research,2018(02):62-72.

[12] Shi X. K., Dong X. H., Li Z. F. Financing constraints and financing structure of R\&D investment of Gem enterprises in China: Based on SA financing constraint Index [J]. Zhejiang Finance,2017(10):42-50.

[13] Tang X. D., Lin Y. J., Xiao Q. Investors focus on the enterprise life cycle impact on equity capital cost [J]. Journal of Xiamen institute of technology, 2021, 29 (6): 27-35. DOI: 10.19697 / j. carol Carroll nki. $1673-4432.202106005$. 
[14] Wang B., Li L., Wu W. J. Can stock market opening alleviate financing constraints of private enterprises: Evidence from the Launch of Shenzhen-Hong Kong Stock Connect [J]. Journal of Financial Economics, 201, 36(03):107-123.

[15] Wang J. Analysis and evaluation of financing constraints of listed manufacturing companies -- taking SA index measurement method as an example [J]. Finance and Accounting Monthly,2015(21):63-66.

[16] Wang J., Ding Y. Capital market opening and resource allocation efficiency in the context of ShanghaiShenzhen-Hong Kong Stock Connect: The Mediating effect based on information transparency [J]. Yunnan Social Sciences,2020(04):122-128.

[17] Wang Y. F., Zhang Y. The impact of the establishment of free trade zone on urban total factor productivity -- Also on the mediating effect of capital mismatch and the moderating effect of industrial agglomeration [J]. Soft science, 2021, 35 (11): 52-57, DOI: 10.13956 / j. s. 1001-8409.2021.11.09.

[18] Whited T. M., Wu G. Financial constraints risk[J]. The Review of Financial Studies, 2006, 19(2): 531559.

[19] Xin Y.Y., Xu P. Z. Capital market opening and firm investment efficiency: Empirical evidence from shanghai-Hong Kong Stock Connect [J]. China Certified Public Accountants,2019(04):76-81.

[20] Yang L. Y., Zhang Z. Y. The impact of green credit policy on enterprise green innovation [J/OL]. Studies in Science of Science :1-23[2021-08-23].

[21] Yu J. Y. Financing constraints, institutional investors' ownership and firm value [J]. Modern Business, 2021 (27):137-140.

[22] Zhang Z. S. Research on the change of systemic financial risk in stock market before and after ShanghaiHong Kong Stock Connect [J]. Time Finance,2020(32):25-29.

[23] Zhen H. X., Wang Z. Can institutional investors ease financing constraints? -- From the perspective of cash value [J]. Accounting Research,2016(12):51-57+96.

[24] Zhou F., Lu S. Y. The influence of Shanghai-Hong Kong Stock Connect on the level of voluntary information disclosure of enterprises [J]. China Circulation Economy,2021(12):52-55. 